\title{
Kesiapsiagaan Masyarakat Di Desa Dukun Kecamatan Dukun Kabupaten Magelang Kawasan Resiko Bencana ( KRB ) III dalam Penanggulangan Bencana
}

\author{
Margono', M.Khoirul Amin², Retna Tri Astuti ${ }^{3}$ \\ Universitas Muhammadiyah Magelang, Indonesia \\ 1'margono@ummgl.ac.id, ${ }^{2}$ khoirulamin@ummgl.ac.id, ${ }^{3}$ retnatriastuti@ummgl.ac.id
}

\begin{tabular}{l}
\hline INFORMASI ARTIKEL \\
\hline Sejarah artikel: \\
Diterima: 06-11-2019 \\
Publikasi: 26-12-2019
\end{tabular}

Kata kunci:
Kesiapsiagaan,
Mayarakat,
Bencana,
Magelang

\section{Key word:}

Preparedness, Society, Disaster, Magelang

\begin{abstract}
ABSTRAK
Kabupaten Magelang merupakan salah satu kawasan yang berada di lereng gunung merapi dengan resiko bencana paling besar adalah meletusnya gunung berapi. Desa Dukun adalah salah satu kawasan rawan bencana gunung merapi yang berada sekirat $8 \mathrm{~km}$ dari puncak gunung dan masuk daram Kawasan Resiko Bencana III di Kabupaten Magelang. Pada letusan pada tahun 2010 sebagian besar masyarakat dukun mengungsi ke Kecamatan lain untuk menghindari awan panas. Gunung berapi yang berada dimagelang berstatus waspada mulai 21 Mei 2018. Dalam kurun waktu 1,5 tahun beberapakali gunung berapi mengeluarkan abu vulkanik dan gempa. Dengan keadaan tersebut, resiko bencana di masyarakat sangat tinggi terutama yang dikawasan KRB III Gunung Merapi. Penanggulangan bencana berbasis masyarakat perlu ditingkatkan terutama persiapan dalam kesiapsiagaan menghadapi bencana. Metode: jenis penelitian ini adalah diskriptif kuantitatif, dengan metode analisis surve lapangan menggunakan kuesioner tentang kesiapsiagaan warga masyarakat desa Dukun yang berada di KRB III dalam menghadapi bencana. Hasil: Hasil penelitian menunjukkan analisa masyarakat terhadap resiko bencana di desa dukun adalah letusan gunung berapi dengan prosentase 96\% dari masyarakat, sumber informasi yang didapatkan masyarakat terhadap bencana 89 \% menunjukan dari perangkat desa, sebanyak 74\% keluarga telah mengikuti sosialisasi bencana namun mayoritas hanya kepala rumah tangga, sebanyak 66\% sudah berupaya pengurangan resiko bencana dan sebanyak 33,5\% masyarakat jika terjadi berencana akan mengungsi kesaudara. Kesiapsiaagaan keluarga dalam menyiapkan perlengkapan P3K masih sangat rendah. Kesimpulan: Masyarakat Desa Dukun telah menyadari bahwa berada dikawasan rawan bencana, saat ini mayoritas keluarga sudah mengikuti sosialisasi kesiapsiagaan namun dalam pengurangan resiko bencana dan persiapan masih kurang
\end{abstract}


much as $66 \%$ have sought disaster risk reduction and as many as $33.5 \%$ of the community if there is a plan to evacuate siblings. Family preparedness in preparing first aid kits was still very low. Conclusion: The Dukun Village community has realized that being in a disaster-prone area, at present the majority of families have participated in preparedness socialization but in disaster risk reduction and preparation is still lacking.

\section{PENDAHULUAN}

Bencana Alam merupakan salah satu fenomena alam yang mengancam keberlangsungan hidup manusia. Dampak negatif yang ditimbulkan bisa berupa kerugian materi maupun nonmateri. Bencana tersebut bisa dicontohkan seperti banjir, tanah longsor, gempa bumi ada pula bencana non alam seperti kebakaran gagal teknologi, gagal modernisasi, konflik sosial antar kelompok (Pangestu, 2010). Indonesia memiliki catatan kejadian bencana yang cukup tinggi. Kejadian bencana di Indonesia disebabkan oleh letak geografis Indonesia terletak diantara lempeng aktif samudera yang menyebabkan berbagai wilayah Indonesia rawan bencana letusan gunung api, gempa dan tsunami. Selain dari letak alam, Indonesia juga harus menghadapi bencana berbasis hidrometerologis seperti kekeringan, angin topan, gelombang pasang dan banjir yang selanjutnya melahirkan bencana turunan seperti tanah longsor, banjir bandang, kurang gizi dan konflik. Kondisi tersebut menempatkan penduduk Indonesia rentan menjadi korban dari sisi sosial, ekonomi dan budaya. Selain di tingkat komunitas, bencana juga melumpuhkan pelayanan publik seperti rumah sakit dan sekolah.

Kabupaten Magelang mempunyai karakteristik wilayah pegunungan. Salah satu bencana yang sering terjadi adalah longsor, banjir kekeringan dan sangat berpotensi terjadinya letugsan gunung berapi. Keberadaan Gunung merapi menjadikan potensi besar terjadinya bencana letusan dan awan panas. Terjadinya letusan gunung berapi diawali dengan kondisi panas di dalam bumi yang telah melebih ambang batasnya, sehingga dari kawah keluar uap air dengan jumlah yang besar dan panas serta membawa benda-benda seperti abu, lava, kerikil, batuan, pasir,dan bahan lainnya. Tanah berguncang dan terjadi suara gemuruh, hingga jalur gas dan benda-benda padat yang keluar banyak dari puncak gunung berapi secara tegak lurus dengan menyembur keatas (Purnomo, 2011).

Pada tahun 2010 tepatnya pada tanggal 26 oktober sampai 5 november 2010 merupakan puncak aktifitas gunung berapi. Dampak dari letusan gunung berapi yang yaitu akan menyebabkan gangguan bagi kehidupan manusia, dampak tersebut dapat mempengaruhi fisik, psikologis, tatanan infrastruktur, social, dan ekonomi (Yuwana, 2018). Maka dari itu masyarakat perlu melakukan antisipasi terhadap bencana. Menurut penelitian yang dilakukan oleh Pradana (2016) menyatakan bahwa terdapat dua desa dikecamatan dukun yang merupakan zona resiko tinggi diantaranya adalah Desa Dukun. Sehingga desa dukun tergolong di zona / kawasan resiko bencana ( KRB) III di Kabupaten Magelang.

Gunung berapi yang berada dimagelang berstatus waspada mulai 21 Mei 2018. Dalam kurun waktu 1,5 tahun beberapakali gunung berapi mengeluarkan abu vulkanik dan gempa. Meningkatnya pertumbuhan penduduk masyarakat kabupaten Magelang terutama dikawazan zona merah menunjukan tingginya ancaman bencana. Disamping itu kapasitas masyarakat yang kurang terhadap kesiapsiagaan juga akan menyebabkan tingginya resiko bencana. Dengan keadaan tersebut, maka perlunya masyarakat harus melakukan mitigasi dan peningkatan kesiapsiagaan terutama pada sektor kesehatan.Tujuan penelitian ini adalah satu upaya untuk memetakan kesiapsiagaan masyarakat di KRB III gunung merapi terutama di wilayah desa Dukun kecamatan Dukun Kabupaten Magelang. Upaya kesiapsiagaan merupakah hal yang wajib dipersiapkan oleh masyarakat terutama untuk mengenali ancama bencana, pengurangan resiko bencana, upaya kesiapsiagaan terutama di sektor kesehatan.

\section{METODE PENELITIAN}

Dalam penelitian ini, pengambilan data menggunakan pemetaan perilaku pada masyarakat (Susanto, 2015) melalui pengukuran indeks kesiapsiagaan warga masyarakat desa Dukun kecamatan dukun dengan penyebaran kuesioner sebanyak 119 Keluarga di dusun Musuk, Duren, Garung, danb Japunan. Materi kuesioner mencakup pengkajian resiko bencana dalam keluarga, 
pengurangan resiko bencana dalam keluarga, indeks kesiapsiagaan keluarga dan tanggap darurat. Pengolahan data dilakukan berdasarkan metode penentuan indeks kesiapsiagaan ( Nugroho, 2007).

\section{HASIL}

\section{Karakteristik Responden}

Dari hasil pengkajian, responden yang mengisi sebanyak $71 \%$ diisi oleh kepala ruamh tangga, $16 \%$ diisi oleh ibu rumah tangga dan $13 \%$ disi oleh anak.

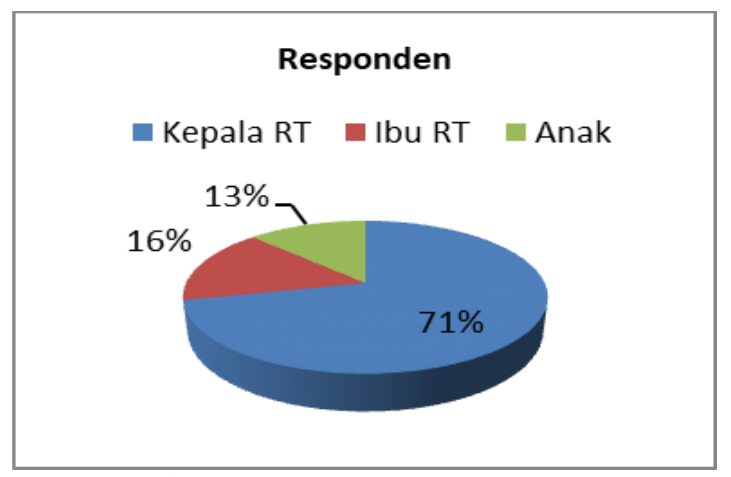

Grafik Karakteristik Responden

\section{Kajian Resiko bencana}

Berdasarakan kajian resiko bencana terhadap tingkat resiko bencana dan dampak yang ditimbulkan didapatkan hasil resiko bencana yang dirasakan masyarakat sebanyak 96\% menyatakan letusan gunung berapi, yang diikuti oleh banjir lahar dingin, dan bencana kebakaran. Sedangkan longsor dan badai masyarakat menilai ancaman resiko yang rendah.

\begin{tabular}{|l|l|c|}
\hline No & $\begin{array}{l}\text { Jenis Ancaman Desa } \\
\text { Dukun }\end{array}$ & kategori \\
\hline 1 & $\begin{array}{l}\text { Gunung } \\
\text { meletus/erupsi }\end{array}$ & Tinggi \\
\hline 2 & Banjir lahar dingin & Sedang \\
\hline 3 & Gempa bumi & Rendah \\
\hline 4 & Longsor & Rendah \\
\hline 5 & Kebakaran & Rendah \\
\hline 6 & Badai/ angin & Rendah \\
\hline
\end{tabular}

Tabel 1 : Tingkat resiko ancaman bencana

\section{Mitigasi Bencana}

Dari hasil analisa data menyatakan bahwa masyarakat sudah menyiapkan mitigasi bencana namun belum optimal. Contohnya seperti bangunan rumah, penataan pintu, jalur evakuasi dan informasi kebencanaan. Namun yang menyiapkan mitigasi bencana tentang kesehatan hanya $7 \%$.

\section{Kesiapsiagaan dan tanggap bencana} Secara umum, hasil menunjukan bahwa informasi bencana yang didapatkan oleh masyarakat Desa Dukun berdasarakan informasi dari perangkat desa yaitu $89 \%$ responden. Selain itu sebanyak 74\% keluarga telah mengikuti sosialisasi bencana namun mayoritas hanya kepala rumah tangga, sebanyak 46\% mayarakat telah melakukan upaya rencana dan pengurangan resiko bencana dengan 33,5\% masyarakat mempunyai rencana akan mengungsi ke saudara jika terjadi bencana. Namun dalam upaya kesiapsiagaan dalam bidang Pertolongan Pertama pada kecelakaan ( P3K) hanya 7 \% keluarga yang menyiapkan saat ini dikarenakan masih dalam situasi normal.

\begin{tabular}{|c|c|c|}
\hline No & Bidang kesiapsiagaan & $\%$ \\
\hline 1 & $\begin{array}{l}\text { Pemantauan informasi } \\
\text { kebencanaan dari desa }\end{array}$ & 89 \\
\hline 2 & $\begin{array}{l}\text { Keikutsertaan sosialisasi } \\
\text { kebencanaan }\end{array}$ & 74 \\
\hline 3 & Pengurangan resiko bencana & 33,5 \\
\hline 4 & Kesiapsiagaan dalam P3K & 7 \\
\hline
\end{tabular}

Tabel 2 : Kesiapsiagaan masyarakat

Dalam pengurangan resiko bencana, masyarakat sebagian besar dalam keluarga sudah mengikuti sosialisasi bencana, namun sosialisasi hanya sebatas pada keluarga saja, tidak ada penyampaian kepada anggota keluarga yang lain. Sedangkan informasi yang didapatkan keluarga dalam kebencanaan masih dalam informasi dari pemerintah desa baik melalui pesan singkat ataupun informasi melalui media penyiaran umum ( spekir di masjid). Dalam bidang kesehatan masyarakat menganggap masih dalam kondisi aman sehingga tidak menyediakan obat obatan. Ketrampilan dalam bidang penanganan darurat juga masih rendah.

\section{PEMBAHASAN}

Bencana dapat terjadi kapan saja, dimana saja dan akan menimpa siapa saja. Kajian resiko bencana merupakan suatu hal yang sangat penting dalam upaya penanggulangan bencana. Keterlibatan masyarakat dalam penanggulangan bencana dari perencanaan prabencana sampai rehabilitasi sangat membantu pemerintah dalam meminimalisir dampak kerugiian bencana. Kesiapsiagaan adalah usaha persiapan/ siap siap mengahdapi dampak sesuatu yang tujuannya adalah untuk membangun kesiapan pemerintah dan stakeholder dalam menanggulangi 
bencana serta membangun ketahanan individu, masyarakat, kegiatan sosial, dan ekonomi ( Prawirodikromo, 2012).

Dalam penelitian ini dapat kita lihat bahwa masyarakat Desa Dukun Kecamatan Dukun Kabupaten Magelang telah menyadari adanya resiko bencana yang sangat tinggi yaitu letusan gunung merapi yang berjarak kurang lebih 8 KM dari puncak gunung. Gunung merapi merupakan salah satu gunung yang aktif di Indonesia dengan mengeluarkan lava besar durasi 5-7 tahunan mengalami letusan. Maka dari itu peran dan upaya pemerintah dalam melakukan penanggulangan bencana perlu selalu dilakukan secara contineu. Menurut Undang-undang No 24 tahun 2007, kerentanan adalah suatu kondisi atau karakteristik biologis, geografis, sosial, ekonomi, politik, bdaya dan teknologi suatu masyarakat disuatu daerah yang mengurangi kemampuan masyarakat untuk mencehgah/ meredam mencapai kesiapan dan menanggapi dampak tertentu. Maka dari itu upaya pemerintah melalui lembaga desa telah berupaya dalam melakukan upaya penanggulangan bencana dengan sosialisasi kepada masyarakat dibuktikan dengan $74 \%$ responden telah mengikuti sosialisasi bencana. Namun jika dilihat dari kepesertaan yang mengikuti sosialisasi adalah mayoritas kepala rumah tangga ( 81\%) dan pemuda (15\%). Data menunjukan bahwa keterlibatan ibu ibu rumah tangga masih kecil yaitu sebesar $4 \%$ yang mengikuti sosialisasi.

\section{Keikutsertaan sosialisasi}

— kepala RT — Ibu RT — Pemuda/ Anak

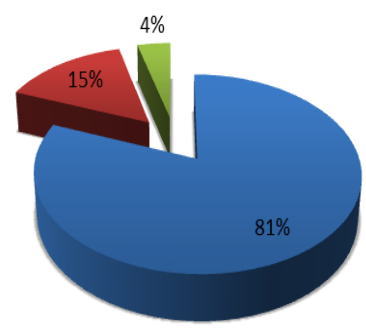

Grafik 1 : Data keikutsertaan sosialisasi bencana dalam keluarga

Dari penelitian ini menunjukan bahwa besar besaran keluarga dalam mengikuti sosialisasi menunjukan bahwa masyarakat telah berupaya melakukan mitigasi dan kesiapsiagan. Namun yang masih sangat kurang pada kesiapsiagaan tentang kesehatan. Hal tersebut dikarenakan masyarakat mayoritas sebagai seorang petani dan buruh dan masih kurang dalam pengetahuan dalam bidang kesehatan. Menurut Bakornas (2007) keluarga diharapkan dapat melakukan kesiapsiagaan diantaranya adalah penyediaan tas siaga yang berisi surat penting, makanan dan obat-obatan. Maka dari itu pemahaman keluarga terhadap bencana sangatlah diperlukan terutama penyediaan obat obatan sederhana dalam rumah.

Selain itu untuk meminimalisir kerugian terhadap bencana terutama menghindari korban jiwa maka perlunya peningkatan terhadap upaya kesiapsiagaan terhadap resiko bencana. Peran dari pemerintah desa dukun terlihat sangat baik yang dapat dilihat dari $89 \quad \%$ segala informasi yang didapatkan oleh masyarakat bersumber dari perangkat desa. Dari hasil kajian menunjukan bahwa pemerintah desa dukun sangat aktif dan memperhatikan dalam upaya penanggulangan bencana. Dibuktikan dengan masyarakat desa dukun sudah terbentuk organisasi Pengurangan Resiko Bencana ( OPRB) tingkat desa dan sebaian pemuda tergabung dalam Taruna Siaga Bencana ( TAGANA) dari kemetrian sosial yang bergerak dalam bidang sosial. Penelitian ini menegaskan penelitian Sukandar (2017) bahwa kesiapsiagaan bencana perlu ada peran aktif masyarakat yaitu dapat berupa pembentukan tim satgana dan tim sibat. Tim siaga ini berfungsi untuk melindungi dan merespon cepat terhadap bencana yang terjadi diwilayah tersebut.

Selain hal tersebut penelitian ini menunjukan program sosialisasi kebencanaan kepada masyarakat desa Dukun juga baik dengan $74 \%$ keluarga sudah mengikuti kegiatan sosialisasi baik itu tingkat desa maupun sampe tingkat kabupaten. Namun beberapa yang masih perlu ditingkatkan yaitu penerusan informasi ke anggota keluarga. Data menunjukan bahwa informasi kebencanaan masih sebatas kepada peserta sosialisasi saja. Sehingga anggota keluarga sebagian besar tidak mendapatkan hasil dari sosialisasi.

Penelitian ini menunjukan realisasi peraturan bupati Kabupaten Magelang tahun 2016 tentang tahapan penyelenggaraan penanggulangan bencana pada tahap prabencana. Dengan adanya 
kegiatan sosialisasi ini maka masyarakat akan dapat melakukan kewaspadaan dan kesiapsiagan dalam mengantisipasi korban bencana. Status waspada gunung berapi kabupaten magelang yang ditetapkan semenjak 21 mei 2018 merupakan suatu peringatan dini agar masyarakat melakukan perencanaan yang baik dalam melakukan antisipasi bencana. Sedangkan upaya pengurangan resiko bencana masyarakat sebanyak 66\% telah melakukan dengan kegiatan yaitu dengan upaya pengenalan peta rawan bencana, upaya mitigasi bencana dan simulasi terhadap bencana. Dalam hal pengungisan telah dilakukan perencanaan program sister vallage dengan melakukan koordinasi terhadap desa di KRB dengan desa di wilayah aman dikabupaten Magelang. Penelitian ini menegaskan penelitian yang dilakukan oleh Kaharjono (2018) yang menunjukan manajemen komunikasi dalam penanggulangan bencana dikabupaten Magelang sudah baik yaitu dengan metode sister vallage dan dan program desa tangguh bencana.

Dalam upaya pelatihan pelatihan kesiapsiagaan terutama dalam pertolongan pertama masyarakat masih kurang. Hal ini di buktikan dengan hanya 27\% yang mempunyai kotak P3K dan isinya. Sedangkan dari hasil pendataan mereka belum menyiapakan karena saat ini gunung berapi masih dalam keadaan normal/ belum mebahayakan. Sedangkan jika sudah ada tanda tanda akan beresiko terjadi letusan masyarakat sudah menyiapkan satu tas yang berisi pakaian, makanan, surat penting dan P3K. Penelitian yang dilakukan oleh pahlevianur (2019) menunjukan pentingnya edukasi sadarbencana melalui sosialisasi kebencanaan terutama upaya peningkatan pengetahuan. Penelitian ini juga mengevaluasi dari penelitian yang dilakukan Kaharjono ( 2018) bahwa badan penanggulangan bencana ( BPBD) kabupaten Magelang melakukan upaya masyarakat sadar tentang bencana dengan diadakan sosialisasi bencana erupsi merapi keterkaitan aktivitas gunung berapi. Sosialisasi yang dilakukan terbagi menjadi kelompok kelompok pemerintah desa, komunitas dan pendidik.

Program pelatihan merupakan suatu upaya dalam melakukan pemahaman terhadap penanganan bencana. Salah satu program pelatihan yang diminati adalah pelatihan penanganan kegawat daruratan di masyarakat. Tujuan ini sebagai langkah upaya kesiapsiagaan masyarakat apabila disaat bencana dapat memberikan pertolongan pertama. Sebagai narasumber dalam program pelatihan yang diselenggarakan oleh BPBD Kabupaten magelang dari Rumah sakit/ puskesmas, MDMC dan PMI. Namun karena keterbatasan masyarakat yang tidak mempunya latar belakang medis/ perawat menjadi pemahaman pertolongan pertama masih kurang. Masih banyak yang menggunakan cara cara penanganan konfensional. Disamping itu peserta pelatihan juga diikutsertakan dalam kegiatan simulasi bencana yang melibatkan banyak sektor dalam penanggulangan bencana diantaranya pemerintah, dunia usaha dan masyarakat itu sendiri.

\section{KESIMPULAN DAN SARAN Kesimpulan}

Dari hasil penelitian tentang kesiapsiagaan masyarakat di KRB III gunung merapi menunjukan bahwa :

1. Masyarakat secara umum menyadari bahwa resiko bencana yang berada di Desa dukun Kecamatan Dukun adalah Letusan/Erupsi gunung Merapii.

2. Dalam upaya sosialisasi kesiapsiagaan masyarakat sebagian besar keluarga sudah mengikuti sosialisasi tentang kebencanaan namun hasil sosialisasi tersebut masih kepada peserta dan belum disosialisasi kepada anggota keluarga masing masing.

3. Sumber informasi kebencanaan mayoritas dari pemerintah desa.

4. Dalam upaya kesiapsiagan penanggulangan bencana desa Dukun Kecamatan Dukun kabupaten Magelang sudah baik masyarakat sudah baik dengan mengikuti pelatihan, sosialisasi dan simulasi.

5. Masyarakat masih kurang pemahaman dalam pertolongan pertama dan penyediaan alat alat $\mathrm{P} 3 \mathrm{~K} /$ obat obatan.

\section{Saran}

1. Bagi BPBD kabupaten Magelang

Perlu peningkatan kapasitas masyarakat dalam penanggulangan bencana seperti pelatihan dan simulasi yang dilakukan secara terprogram dan berkesinambungan

2. Bagi Pemerintah Desa Dukun

Perlunya pemberdayaan masyarakat dengan penanggulangan bencana 
berbasis masyarakat dan penguatan kepada OPRB yang sudah terbentuk

3. Bagi Mayarakat

Perlunya kesadaran terhadar ancaman resiko bencana, dengan peningkatan kewaspadaan dan peningkatan kapasitas yang dimiliki keluarga terutama dalam pertolongan pertama dan penyediaan obat obatan sederhada di rumah.

\section{DAFTAR PUSTAKA}

Anggiani, Raysa Relegia. (2016). “ Evaluasi Mitigasi Bencana Gunung Merapi di Kawasan Wisata Lava Tour Merapi Kabupaten Sleman." Skripsi Sarjana, Fakultas Teknik Universitas Gadjah Mada,Yogyakarta

BNPB. (2017). Data Kejadian Bencana 2016, (Online), (http://dibi.bnpb.go.id/Des Inventar/about.jsp, diakses tanggal 30 Januari 2017).

Bakornas-PB. (2007). Pengenalan Karakteristik Bencana dan Upaya Mitigasinya di Indonesia Edisi II. Jakarta Pusat: Direktorat Mitigasi

Direktorat Kesiapsiagaan Badan Nasional Penanggulangan bencana (2012). "Pedoman Penyelenggaraan Latihan Kesiapsiagaan Penanggulangan Bencana

Finnis, Kristen K, David M. Johston, Kevin R. Ronan, et al. (2010). Hazard Perception and Preparedness of Taranaki Youth. Disaster Prevention and Management Journal, 19, (2), 178

Hammad, K.S. (2011). Emergency Nurse and Disaster Response: An Exploration of South Australian Emergency Nurses' Knowledge of Their Roles in Disaster Response. Australian Emergency Nursing Journal, 14, 4-6

Niswanta., Erupsi Gunung Api Merapi 2010 Pemantauan, Penanggulangan dan Peran Masyarakat. "Manajemen Komunikasi Waktu Penunjang Keberhasilan Mitigasi Bencana G.Merapi”. (Pusat Vulkanologi dan Mitigasi Bencana Geologi)

Nugroho, (2007) Kajian Kesiapsiagaan Mayarakat Dalam mengantisipasi bencana Gempa bumi dan tsunami di nias selatan. MPBI-UNESCO 2-20 April 2007

Kurniawan,Dewi.,(2016)

Pengaruh pengetahuan terhadap sikap kesiapsiagaan dalam menghadapi bencana pada mahasiswa program studi pendidikan geologi universitas kanjuruhan malang ( Skripsi) universitas Kanjuruhan Malang

Lestari, Puji, et., al.(2016) "Komunikasi Lingkungan untuk Mitigasi Bencana Erupsi Gunung Sinabung," Jurnal ASPIKOM, Volume. 3. Hal. 56-64

Pahlevi (2019) “ Edukasi sadar bencana melalui sosialisasi kebencanaan sebagai upaya peningkatan pengetahuan siswa terhadap mitigasi bencana" jurnal JPIS,Vol 29, No 1 Juni 2019 hal 49-55

Peerbolte,Stacy L. \& Matthew Lloyd Collins.(2013) "Disaster management and the critical thinking skills of local emergency managers: correlations with age, gender, education, and years in occupation". Journal Compiliation, Volume. 37. p. 48-60

Peraturan Bupati Magelang nomor 18 tahun 2016 Tentang Rincian kegiatan dalam tahapan penyelenggaraan penanggulangan bencana Kabupaten Magelang

Pradana, (2016) : kajian zona bahaya erupsi gunung merapi terhadap pemukiman di kabupaten Magelang (skripsi) Universitas Negeri Semarang

Prawirodikromo, Widodo ( 2012). Seismologi Teknik rekayasa kegempaan Yogyakarta : pustaka pelajar

Ristrini (2012). Anilisis impolementasi kebijakan kesiapsiagaan penanggulangan bencana bidang kesehatan prov sumatra utara. Buletin penelitian kesehatan vol 15 no 1 Januari 2012

Sudibyo Joko. "Erupsi Gunung Merapi (2010) : sister village Sebuah Konsep Penanganan Bencana Terintergrasi." Bandung: Pusat Vulkanologi dan Mitigasi Bencana Geologi

Susanto, (2015). How to develop a humancentered design of disaster management based on the human factor toolkits?: A case study of landslides area in Semarang City. Presented in the 2015 International Conference on Industrial 
Engineering Theory, Methodology, and Application. Yogyakarta, 27-28 Oktober 2015

Undang Undang Republik Indonesia Nomor 24 Tahun 2007 tentang Penanggulangan Bencana. (2007). Jakarta: Masyarakat Penanggulangan Bencana Indonesia (MPBI) 